\title{
Textbook Development Of Game Education Tools In Courses Oriented To Contextual Approach To Improve Student Learning Outcome at PIAUD Bachelor
}

\author{
Nur Fitriyanti, Mustaji, \& Rachma Hasibuan \\ Universitas Negeri Surabaya \\ Surabaya, Indonesia \\ nurfitriyanti038@gmail.com
}

\begin{abstract}
This study aims to develop and test the feasibility, and the effectiveness of Contextual Teaching and Learning (CTL) -oriented textbooks of educational game. The observation model and the Dick and Carey development model were used in this research. The results show that CTL-oriented textbooks are worthy and effective. The use of CTL-oriented textbooks influences students' learning outcomes. The use of CTL-oriented textbooks as learning media also received a good response from students of PIAUD STAI YPBWI Surabaya. Therefore, it can be concluded that CTL-oriented textbooks are feasible and effective to improve students' learning outcomes in APE courses of S1 PIAUD.
\end{abstract}

Keywords - APE textbook; contextual approach; student learning outcomes

\section{INTRODUCTION}

The position of education as a guarantee of the development of the nation's activities and make the benchmarks of society's progress. Physically education is the spearhead of national development, it can even be linked that the advancement of a nation can be seen on how the progress of the education is, both in terms of facility and quality. The deliberate act of fully developing individuals is an activity of education, which is why the problem becomes ever-changing as the subject and the object of education are all human beings. For that, Indonesian people have a decent right to get an education, as Described in National Education System Act Chapter II article 320 of 2003[1].

In the PIAUD S1 course there is an Educational Game Equipment course (hereinafter read APE) is one of the materials that entered in the Quality Control Exam for students at undergraduate program of PIAUD (Early Childhood Islamic Education Program), Islamic High School (STAI) YPBWI, Surabaya. This material has the objective of delivering the skills, creativity, and results of APE products themselves from the idea of students who will improve their competence. The goal will be more easily achieved with the help of supporting resources in the lectures. In the lecture, students need an APE textbook, which will help the lecturing process of PIAUD S1 students.

One of the general goals of APE learning is that students develop their skills, creativity, and competence. The way is implemented as a root for science. With APE humans can be creative, share experiences, learn to each other to improve the ability to create, as well as a means to gain that understanding.

Learning APE in universities is expected to give students an insight and knowledge to be more creative, innovative, especially about APE as the base learning in early childhood education (hereinafter reads the AUD). In addition, APE as a bridge in early childhood to understand the game tools and how to develop the tool for the childhood education. APE is absolutely essential to develop the entire direction of the AUD change. The dimension is expanded so that it is expected to accompany further education. Students must be able to create and develop an AUD game tool because the more developed the tool is, the more interesting it will be.

The textbook is a students' written handbook by an expert, who understands the key of guiding principle (Minister of National Education No.36 / D / O / 201, article 5, verse 9)[2]. Then there is the difference between textbooks with textbooks because textbooks are prepared with provisions and rules that support students' learning.

The textbook is useful as a crucial tool in fulfilling the national education system because it is very influential. For that, the textbook will be prepared according to the needs, characteristics of students, with relevant approaches to the purpose of learning, since there is always an update in the language, content, and curriculum.

In fact, textbooks used in universities are still not feasible. Therefore, it is necessary to conduct further study on the development of textbooks in accordance with applicable eligibility standards. The way of analyzing refers to the 
formulation of evaluation of textbook assessment which will be determined by BSNP (2006)[3].

Based on this, the researchers considered that the development of other textbooks is absolutely necessary. These textbooks should be packed in such a way, so the book meets the students' characteristics during the lectures.

Students can use the textbook independently effectively and efficiently. For lecturers, the existence of textbooks can improve the students' creativity, professionalism, reference and intellectual to always be in accordance with the development of the times (up to date).

One of the educational institutions expected to develop the mandate of the law on national education is the Islamic High School YPBWI Surabaya (STAI-YPBWI) Surabaya. To be able to create a good quality of educational resources, the lecturers need to develop a well, effective and efficient learning. To support the achievement of such learning, then STAI YPBWI Surabaya is expected to be able to develop learning support tools such as textbooks.

The contextual approach developed in the APE textbook is intended to assist students in interpreting real-life learning. In the research will be described the description of students' learning outcomes through textbooks that are developed with a contextual approach[4]. In order to make the learning process more interesting and easier to apply, then the analogies of the Contextual Teaching and Learning approach elaborated by using the developed textbooks to improve students' learning outcomes of PIAUD Department of STAIYPBWI Surabaya. This study aims to explain the quality, effectiveness, and review the students who have used this textbook in improving their learning outcomes.

Based on the meaning and essence of the contextual approach, the researcher assumes that students' learning outcomes will be better if they have been introduced with a contextual approach. So that general problem can be formulated as research questions such as, whether the integration of contextual approach in the textbook will be able to improve students' achievement? The general answer to this question will be pursued through the development of textbooks for APE courses, specifically, the development of this textbook is devoted to students of STIA Study Program STIA YPBWI Surabaya. The use of this textbook on the process and learning activities of APE courses can improve the quality of learning outcomes and educational resources. The process and quality of textbook development are referred to BSNP (2007)[3] which is about the standard of writing book. The process begins with material that has been set by the college in the even semester. From CP (developmental achievement) then developed into the quality of textbook. The achievement of the book development seen from the quality of the product (in accordance with the element of material accuracy, presentation, language, and graphics) and the use of textbooks developed (viewed from the point of view of lecturers and students). This study was conducted on S1 students PIAUD at STAI YPBWI Surabaya. The textbook material oriented to the contextual model of the APE course in the PIAUD undergraduate program. The subject is about the conceptual understanding and skills in developing, defining and applying the appropriate APE and relevant to the context of the issues and targets that serve and administer the AUD education program. Based on the explanation above, the research problems were formulated as follows: How is the feasibility of textbooks in the Educational Game Tools course oriented in contextual approach? and How is the effectiveness of the textbooks development in the Educational Game Tools course oriented in a contextual approach?

\section{METHOD}

This is a research and development because this research produces a textbook as contextual oriented learning medium (CTL) to improve student learning outcomes S1 PIAUD. This research using the Dick and Carey model[5] includes 10 general steps, as follows[6]: (1) Identifying the Identity of Instructional Goals: The initial step of the model decides what the researcher wants in the learning to achieve the learning objective may be guided by a particular curriculum or practical experience of student distress on learning, from the analysis performed by the person working in his field for actual learning. (2) Conducting Learning Instructions [7]: After identifying the learning objectives, the learning needs to be determined by the students is to identify the relevant steps to obtain the competencies or skills needed for the students to achieve the objectives. (3) Analyzing Learner and Contexts: Context analysis includes conditions related to the skills learned by the students and the circumstances related to the tasks that the students encounter to apply the knowledge and skills learned. (4) Formulating the Learning Performance Objectives: formulating specific objectives/learning achievements on student creativity after joining the learning program. Skills and skills can be operationalized so that it can be an observer and measured achievement by using tests or the other. (5). Developing a Research Instrument (Develop Assessment Instrument): The next step is to develop an assessment instrument that measures the achievement of student learning outcomes to determine the student's expected ability in the goal. At this stage developed the assessment of cognitive learning results in the form of pretest and posttest, so that the results of effective learning and psychomotor through observation. (6) Developing the Learning Strategy (Develop Instructional Strategy: from the previous five steps, the following will be created a new strategy to achieve the purpose of learning is using textbooks with developed CTL approaches (7) Selecting and developing learning materials (Develop And Select Instructional Materials): At this stage developing the textbook material equated to the results of the analysis and observation in the field Material developed in the type of learning with CTL approach . The textbook developed is tailored to the CTL approach (8) Designing a Formative Evaluation of Instruction: The instrument must be able to assess the student in achieving the formulated learning objectives it is necessary for determining the instrument en evaluation. Dick and Carey recommend a formative evaluation process consisting of three steps, namely: a. Individual testing, b. Small group trial consisting of six or eight subjects, c. Field 
trials involving all subjects in the class of 35 students[5]. During the experiments, researchers conducted observations to find out the learning through the textbook of the CTL approach. (9) Revising Instruction: this stage is to revise the draft textbook with CTL approach. Obtained from the formative evaluation are summarized, analyzed and interpreted to understand the weaknesses of the textbooks in helping students to achieve learning goals. (10) Designing and Conducting Formative Evaluation Of Instruction: In the Dick and Carrey development model, summative evaluation is done after the textbook that has been developed after being evaluated formatively and revised according to the standards used by the assessors in the process of formative evaluation.

The design of the trial is basically implemented as an evaluation step consisting of expert trials, individuals, small groups and large groups. Furthermore, this Expert Test consists of one lecturer of expert's material. The individual trials are 3 students from $6^{\text {th }}$ semester. Small group trial is 7 students from $6^{\text {th }}$ semester. Large group trials amounted to 35 students from $6^{\text {th }}$ semester as a control class. The data collection technique of this research is using questionnaire, test, and observation. The analysis of CTL-oriented textbooks is done through a validation sheet using a Likert scale. The feasibility analysis of CTL-oriented textbooks was conducted through questionnaires for the students during the trial to find out the students' responses about the textbooks[8]. Furthermore, the practicality of textbooks is done when the implementation of the assessment lesson is conducted, every time the students meet the two observers who have been trained so that the observation sheet will be run correctly.

Students' activity is obtained by comparing the average scale given by observer. To know the effectiveness of textbooks with CTL approach that refer to the students' learning outcomes in this research development the experiment is needed. The form of research used in this study was quasiexperimental design using pretest-posttest technique with control group design I, i.e. Selection of experimental groups and control groups in this design is done randomly. Which consists of two groups namely the experimental group and the control group. The steps of the research design are nonequivalent control design, as follows[9]:

1) Giving pretest to experiment group (O1) and control group (O3) to know the initial score before it is given.

2) Giving the treatment of applying contextual learning model in the experimental group while in the control group was not given treatment.

3) Posttest administration in the experimental group (O2) and control group (O4) to find out the final score of both groups.

4) To know the effect of the treatment is by compary the scores of the experimental group with the control group $(\mathrm{O} 2$ - $\mathrm{O} 1)$ - (O3 - O4).

5) This design is an experimental design performed pretest before treatment to know the initial state in each class. The pretest result of the control class is not much different from the pretest of the experimental class, then the pretest result is declared good. After the treatment. After the treatment is completed, posttest is done as a measurement of cognitive learning outcomes in each class to determine the effect of learning with CTL-oriented textbooks.

6) After calculating the average value that performed by two observers, a calculation is used to test the reliability of the observer to know the similarity or agreement between the observer. According to Agusyana [10] the more similar of assessment results between one observer with other observers are, the more coefficient of reliability will be.

7) Therefore, in this study, the SPSS 19 program used to calculate the reliability of Kappa (agreement between assessors) and the criteria according to Fleiss [11]

\section{RESULTS AND DISCUSSION}

The results of the feasibility of CTL-oriented textbooks obtained from validation sheet and media skill questionnaire filled by students. Validated components include the eligibility and effectiveness of textbooks. Meanwhile, the recommended media questionnaires were given to private groups and small groups.

\section{CONCLUSION}

Based on experimental results and discussions, it can be concluded that: (1) CTL-oriented textbooks are very suitable for use in learning APE courses (2) In addition, APE-oriented textbooks are effective for use in the development of educational game tools. The conclusion is based on the percentage of results calculation on observing the learning process, student activities, and the questionnaire of the feasibility and effectiveness of textbooks.

Therefore, it can be concluded that the learning process using CTL-oriented textbooks is effective to improve students' learning outcomes because there is a significant difference in learning outcomes between the experimental group and control group.

\section{REFERENCES}

[1] A. T. Force, "The definition of educational technology," Washingt. DC Assoc. Educ. Commun. Technol., 1977.

[2] "Keputusan Mendiknas. No.36/D/0/2001, Pasal 5 ayat 9 tentang Pengertian Buku Ajara dan Penyebaran Buku Ajar."

[3] B. S. N. Pendidikan, "Bahan Sosialisasi Penilaian Buku Teks Pelajaran Bahasa Inggris SMP/MTs, SMA/MA dan SMK.” Jakarta: BSNP, 2007.

[4] D. P. Nasional, "Pendekatan Kontekstual (Contextual Teaching and Learning) CTL," Jakarta Dep. Pendidik. Nas., 2002.

[5] W. Dick, L. Carey, and J. O. Carey, "The systematic design of instruction," 2005.

[6] T. Belawati, "Materi Pokok Pengembangan Bahan Ajar Edisi ke Satu," Jakarta Univ. Terbuka, 2003.

[7] D. P. Ausubel, "The psychology of meaningful verbal learning.," 1963.

[8] M. Rusijono, "Penelitian Teknologi Pembelajaran." Surabaya: Unesa University Press, 2008.

[9] M. B. A. Riduwan, "Metode dan teknik menyusun tesis," Bandung Alf., 2010.

[10] Y. Agusyana, "Olah data skripsi dan penelitian dengan SPSS 19," Jakarta PT Elex, 2011. 
